\title{
Stimulating Effect of Terfenadine on Erythrocyte Cell Membrane Scrambling
}

\author{
Elena Signoretto ${ }^{a, b, c}$ Michela Castagna ${ }^{c}$ Abdulla Al Mamun Bhuyan ${ }^{a, b}$ \\ Florian Lang ${ }^{\mathrm{a}, \mathrm{b}}$
}

Departments of a Cardiology \& Vascular Medicine and ' ${ }^{2}$ Physiology, University of Tübingen, Tübingen, Germany; 'Department of Pharmacological and Biomolecular Sciences, Università degli Studi di Milano, Milano, Italy

\author{
Key Words \\ Phosphatidylserine $\bullet$ Ionomycin • Eryptosis $•$ Calcium • Terfenadine
}

\begin{abstract}
Background/Aims: The antihistaminic drug Terfenadine may trigger apoptosis of tumor cells, an effect unrelated to its effect on histamine receptors. Similar to apoptosis of nucleated cells, erythrocytes may enter eryptosis, the suicidal death of erythrocytes characterized by cell shrinkage and cell membrane scrambling with phosphatidylserine translocation to the erythrocyte surface. Signaling triggering eryptosis include increase of cytosolic $\mathrm{Ca}^{2+}$ activity $\left(\left[\mathrm{Ca}^{2+}\right]_{\mathrm{i}}\right)$, oxidative stress, and ceramide. The present study explored, whether Terfenadine is capable to trigger eryptosis. Methods: Flow cytometry was employed to estimate phosphatidylserine abundance at the erythrocyte surface from annexin-V-binding, cell volume from forward scatter, $\left[\mathrm{Ca}^{2+}\right]_{i}$ from Fluo3-fluorescence, abundance of reactive oxygen species (ROS) from 2',7'-dichlorodihydrofluorescein (DCF) diacetate dependent fluorescence, and ceramide abundance at the human erythrocyte surface utilizing specific antibodies. Hemolysis was quantified from haemoglobin concentration in the supernatant. Results: A 48 hours exposure of human erythrocytes to Terfenadine $(\geq 5 \mu \mathrm{M})$ significantly increased the percentage of annexin-V-binding cells and triggered hemolysis without significantly modifying the average forward scatter. Terfenadine $(7.5 \mu \mathrm{M})$ significantly increased Fluo3fluorescence, but did not significantly modify DCF fluorescence or ceramide abundance. The effect of Terfenadine on annexin-V-binding was significantly blunted but not abolished by removal of extracellular $\mathrm{Ca}^{2+}$. Exposure of human erythrocytes to $\mathrm{Ca}^{2+}$ ionophore ionomycin (1 $\mu \mathrm{M}, 15 \mathrm{~min}$ ) triggered annexin-V-binding, an effect augmented by Terfenadine pretreatment (10 $\mu \mathrm{M}, 48$ hours). Conclusions: Terfenadine triggers phospholipid scrambling of the human erythrocyte cell membrane, an effect in part due to entry of extracellular $\mathrm{Ca}^{2+}$ and in part due to sensitizing human erythrocyte cell membrane scrambling to $\mathrm{Ca}^{2+}$.
\end{abstract}




\section{Cellular Physiology Cell Physiol Biochem 2016;38:1425-1434 \begin{tabular}{l|l} 
DOI: 10.1159/000443085 & $\begin{array}{l}\text { O 2016 The Author(s). Published by S. Karger AG, Basel } \\
\text { www.karger.com/cpb }\end{array}$
\end{tabular} \\ Signoretto et al.: Terfenadine-Induced Eryptosis}

\section{Introduction}

Terfenadine, a selective histamine $\mathrm{H} 1$ receptor antagonist [1-8], is clinically used against allergic disorders such as hay fever, allergic rhinitis, and other histamine-mediated disorders [6, 8-10]. The substance does not impair psychomotor performance to a similar extent as traditional antihistamines [4, 6-8]. Besides blocking the $\mathrm{H} 1$ receptor, Terfenadine may interfere with degranulation of mast cells and thus decrease histamine release [5]. Terfenadine and related substances may further trigger apoptosis [11-18] and may thus be effective against malignancy $[12-15,17,19-21]$. The effect is unrelated to antihistaminergic activity [11]. Instead, Terfenadine is in part effective by mitochondrial depolarization [16], cytochrome c release [16], oxidative stess [12], increase of cytotosolic $\mathrm{Ca}^{2+}$ activity $\left(\left[\mathrm{Ca}^{2+}\right]_{\mathrm{i}}\right)$ [11] and activation of caspases $[12,15,16]$.

Similar to apoptosis of tumor cells erythrocytes may enter eryptosis, the suicidal death of erythrocytes characterized by cell shrinkage [22] and cell membrane scrambling with breakdown of phosphatidylserine asymmetry of the cell membrane and phosphatidylserine translocation to the cell surface [23]. Signaling involved in the stimulation of eryptosis include $\mathrm{Ca}^{2+}$ entry with increase of $\left[\mathrm{Ca}^{2+}\right]_{\mathrm{i}}[23]$, ceramide [24], oxidative stress [23], energy depletion [23], caspases [23, 25,26], as well as dysfunction of several kinases, such as casein kinase $1 \alpha$, Janus-activated kinase JAK3, protein kinase C, and p38 kinase, PAK2 kinase,AMP activated kinase AMPK, cGMP-dependent protein kinase, and sorafenib/sunitinib sensitive kinases [23].

The present study explored, whether and how Terfenadine modifies eryptosis. To this end, human erythrocytes drawn from healthy volunteers were treated with Terfenadine and phosphatidylserine surface abundance, cell volume, hemolysis, $\left[\mathrm{Ca}^{2+}\right]_{i}$, abundance of reactive oxygen species (ROS) and ceramide determined by flow cytometry.

\section{Materials and Methods}

\section{Erythrocytes, solutions and chemicals}

Fresh Li-Heparin-anticoagulated blood samples were kindly provided by the blood bank of the University of Tübingen. The study is approved by the ethics committee of the University of Tübingen $(184 / 2003 \mathrm{~V})$. The blood was centrifuged at $120 \mathrm{~g}$ for $20 \mathrm{~min}$ at $21^{\circ} \mathrm{C}$ and the platelets and leukocytes-containing supernatant was disposed. Erythrocytes were incubated in vitro at a hematocrit of $0.4 \%$ in Ringer solution containing (in $\mathrm{mM}$ ) $125 \mathrm{NaCl}, 5 \mathrm{KCl}, 1 \mathrm{MgSO}_{4}, 32 \mathrm{~N}$-2-hydroxyethylpiperazine-N-2-ethanesulfonic acid (HEPES; pH 7.4), 5 glucose, $1 \mathrm{CaCl}_{2}$, at $37^{\circ} \mathrm{C}$ for 48 hours. Where indicated, erythrocytes were exposed for 48 hours to Terfenadine (Sigma Aldrich, Hamburg, Germany) or for $15 \mathrm{~min}$ to $\mathrm{Ca}^{2+}$ ionophore ionomycin (Sigma Aldrich, Hamburg, Germany).

\section{Annexin-V-binding and forward scatter}

After incubation under the respective experimental condition, a $100 \mu \mathrm{l}$ cell suspension was washed in Ringer solution containing $5 \mathrm{mM} \mathrm{CaCl}_{2}$ and then stained with Annexin-V-FITC (1:200 dilution; ImmunoTools, Friesoythe, Germany) in this solution at $37^{\circ} \mathrm{C}$ for $20 \mathrm{~min}$ under protection from light. The annexin-Vabundance at the erythrocyte surface was subsequently determined on a FACS Calibur (BD, Heidelberg, Germany). Annexin-V-binding was measured with an excitation wavelength of $488 \mathrm{~nm}$ and an emission wavelength of $530 \mathrm{~nm}$. A marker (M1) was placed to set an arbitrary threshold between annexin-V-binding cells and control cells. The same threshold was used for untreated and Terfenadine treated erythrocytes. A dot plot of forward scatter (FSC) vs. side scatter (SSC) was set to linear scale for both parameters. The threshold of forward scatter was set at the default value of " 52 ".

Intracellular $\mathrm{Ca}^{2+}$

After incubation, erythrocytes were washed in Ringer solution and loaded with Fluo-3/AM (Biotium, Hayward, USA) in Ringer solution containing $5 \mu \mathrm{M}$ Fluo-3/AM. The cells were incubated at $37^{\circ} \mathrm{C}$ for 30 min. $\mathrm{Ca}^{2+}$-dependent fluorescence intensity was measured with an excitation wavelength of $488 \mathrm{~nm}$ and an emission wavelength of $530 \mathrm{~nm}$ on a FACS Calibur. 


\section{Cellular Physiology Cell Physiol Biochem 2016;38:1425-1434

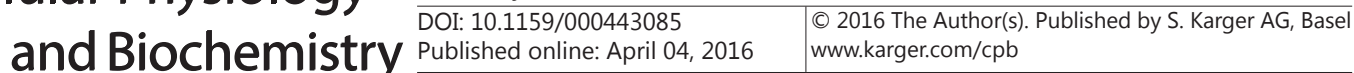 \\ Signoretto et al.: Terfenadine-Induced Eryptosis}

Reactive oxidant species (ROS)

Oxidative stress was determined utilizing 2',7'-dichlorodihydrofluorescein diacetate (DCFDA). After incubation, a $100 \mu \mathrm{l}$ suspension of erythrocytes was washed in Ringer solution and stained with DCFDA (Sigma, Schnelldorf, Germany) in Ringer solution containing DCFDA at a final concentration of $10 \mu \mathrm{M}$. Erythrocytes were incubated at $37^{\circ} \mathrm{C}$ for $30 \mathrm{~min}$ in the dark and washed two times in Ringer solution. The DCFDA-loaded erythrocytes were resuspended in $200 \mu$ linger solution and ROS-dependent fluorescence intensity was measured at an excitation wavelength of $488 \mathrm{~nm}$ and an emission wavelength of $530 \mathrm{~nm}$ on a FACS Calibur (BD).

\section{Ceramide abundance}

For the determination of ceramide, a monoclonal antibody-based assay was used. To this end, cells were stained for 1 hour at $37^{\circ} \mathrm{C}$ with $1 \mu \mathrm{g} / \mathrm{ml}$ anti ceramide antibody (clone MID 15B4, Alexis, Grünberg, Germany) in PBS containing $0.1 \%$ bovine serum albumin (BSA) at a dilution of 1:10. The samples were washed twice with PBS-BSA. The cells were stained for 30 minutes with polyclonal fluorescein isothiocyanate (FITC) conjugated goat anti-mouse IgG and IgM specific antibody (Pharmingen, Hamburg, Germany) diluted 1:50 in PBS-BSA. Unbound secondary antibody was removed by repeated washing with PBS-BSA. The samples were analyzed by flow cytometric analysis with an excitation wavelength of $488 \mathrm{~nm}$ and an emission wavelength of $530 \mathrm{~nm}$. As a control, secondary antibody alone was used.

\section{Statistics}

Data are expressed as arithmetic means \pm SEM. As indicated in the figure legends, statistical analysis was made using ANOVA with Tukey's test as post-test and $t$ test as appropriate. $\mathrm{n}$ denotes the number of different erythrocyte specimens studied. Since different erythrocyte specimens used in distinct experiments have not necessarily identical susceptibility to triggers of eryptosis, the same erythrocyte specimens have been used for control and experimental conditions.

\section{Results}

The present study explored the effect of Terfenadine on suicidal erythrocyte death or eryptosis, which is characterized by cell shrinkage and by break-down of phospholipid asymmetry of the cell membrane with phosphatidylserine translocation to the cell surface.

Forward scatter was determined by flow cytometry as a measure of erythrocyte volume. The measurements were performed after incubation of the erythrocytes 48 hours in Ringer solution without or with Terfenadine $(1-10 \mu \mathrm{M})$. As shown in Fig. 1, Terfenadine did not significantly modify the average erythrocyte forward scatter; Terfenadine tended to decrease the percentage both of swollen and of shrunken erythrocytes, an effect, however, not reaching statistical significance (Fig. 1C, D).

Annexin binding determined by flow cytometry was taken as a measure of cell membrane scrambling with phosphatidylserine exposure at the erythrocyte surface. Prior to measurements, the erythrocytes were again incubated for 48 hours in Ringer solution without or with Terfenadine $(1-10 \mu \mathrm{M})$. As shown in Fig. 2, a 48 hours exposure to Terfenadine increased the percentage of phosphatidylserine exposing erythrocytes, an effect reaching statistical significance at $5 \mu \mathrm{M}$ Terfenadine.

Hemoglobin in the supernatant was determined to quantify the percentage of hemolytic erythrocytes. As illustrated in Fig. 3, a 48 hours exposure to Terfenadine increased the percentage of hemolytic erythrocytes, an effect reaching statistical significance at $5 \mu \mathrm{M}$ Terfenadine concentration. Thus, Terfenadine triggered hemolysis.

Fluo3-fluorescence was employed to measure cytosolic $\mathrm{Ca}^{2+}$ activity $\left(\left[\mathrm{Ca}^{2+}\right]_{\mathrm{i}}\right)$. As illustrated in Fig. 4, a 48 hours exposure to Terfenadine increased the Fluo3-fluorescence, an effect reaching statistical significance at $7.5 \mu \mathrm{M}$ Terfenadine concentration. Thus, Terfenadine increased $\left[\mathrm{Ca}^{2+}\right]_{\mathrm{i}}$.

In order to test whether the Terfenadine-induced translocation of phosphatidylserine was sensitive to extracellular $\mathrm{Ca}^{2+}$, erythrocytes were incubated for 48 hours in the absence 
A

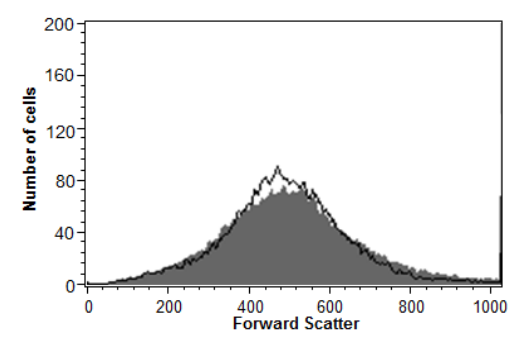

C

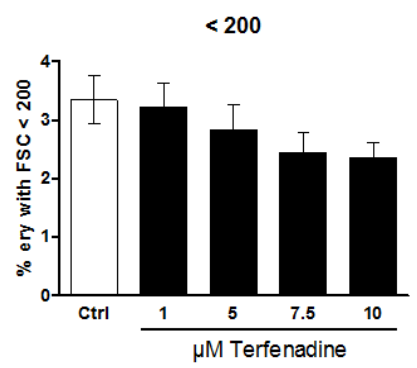

B

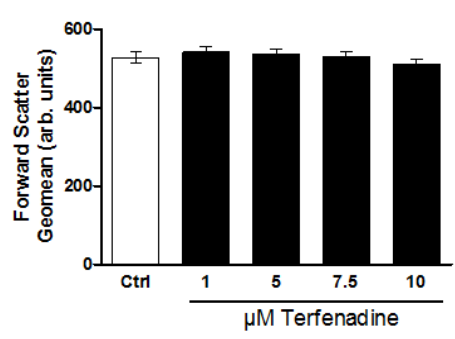

D

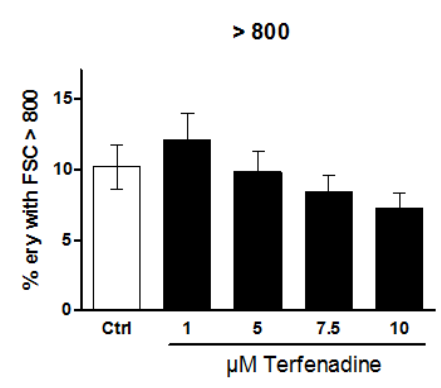

Fig. 1. Effect of Terfenadine on erythrocyte forward scatter. A. Original histogram of forward scatter of erythrocytes following exposure for 48 hours to Ringer solution without (grey area) and with (black line) presence of $10 \mu \mathrm{M}$ Terfenadine. B. Arithmetic means \pm SEM ( $\mathrm{n}=14$ ) of the erythrocyte forward scatter (FSC) following incubation for 48 hours to Ringer solution without (white bar) or with (black bars) Terfenadine $(1-10 \mu \mathrm{M})$. C. Arithmetic means \pm SEM $(n=14)$ of the percentage erythrocytes with forward scatter (FSC) $<200$ following incubation for 48 hours to Ringer solution without (white bar) or with (black bars) Terfenadine $(1-10 \mu \mathrm{M})$. D. Arithmetic means \pm SEM $(n=14)$ of the percentage erythrocytes with forward scatter (FSC) $>800$ following incubation for 48 hours to Ringer solution without (white bar) or with (black bars) Terfenadine $(1-10 \mu \mathrm{M})$.

\section{A}

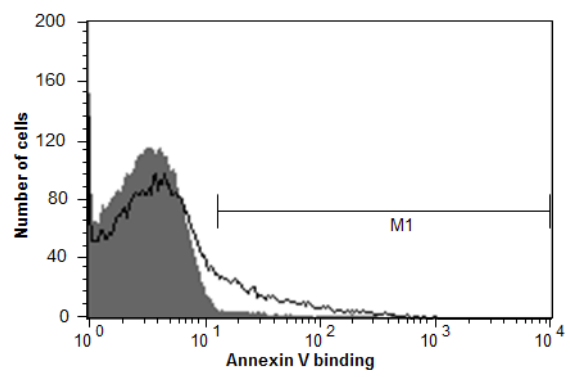

B

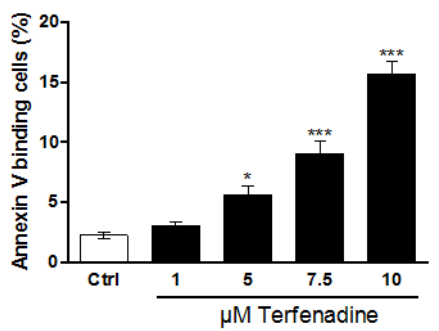

Fig. 2. Effect of Terfenadine on phosphatidylserine exposure. A. Original histogram of annexin-V-binding of erythrocytes following exposure for 48 hours to Ringer solution without (grey area) and with (black line) presence of $10 \mu M$ Terfenadine. B. Arithmetic means \pm SEM $(n=14)$ of erythrocyte annexin-V-binding following incubation for 48 hours to Ringer solution without (white bar) or with (black bars) Terfenadine $(1-10 \mu \mathrm{M}) .{ }^{*}(\mathrm{p}<0.05),{ }^{* * *}(\mathrm{p}<0.001)$ indicates significant difference from the absence of Terfenadine (ANOVA).

or presence of $10 \mu \mathrm{M}$ Terfenadine in the presence or nominal absence of extracellular $\mathrm{Ca}^{2+}$. As shown in Fig. 5, removal of extracellular $\mathrm{Ca}^{2+}$ significantly blunted the effect of Terfenadine on the percentage of annexin-V-binding erythrocytes. However, even in the absence of 
Fig. 3. Effect of Terfenadine on hemolysis. Arithmetic means \pm SEM $(n=14)$ of erythrocyte annexin-V-binding following incubation for 48 hours to Ringer solution without (white bar) or with (black bars) Terfenadine $(1-10 \mu \mathrm{M}){ }^{* * *}(\mathrm{p}<0.001)$ indicates significant difference from the absence of Terfenadine (ANOVA).
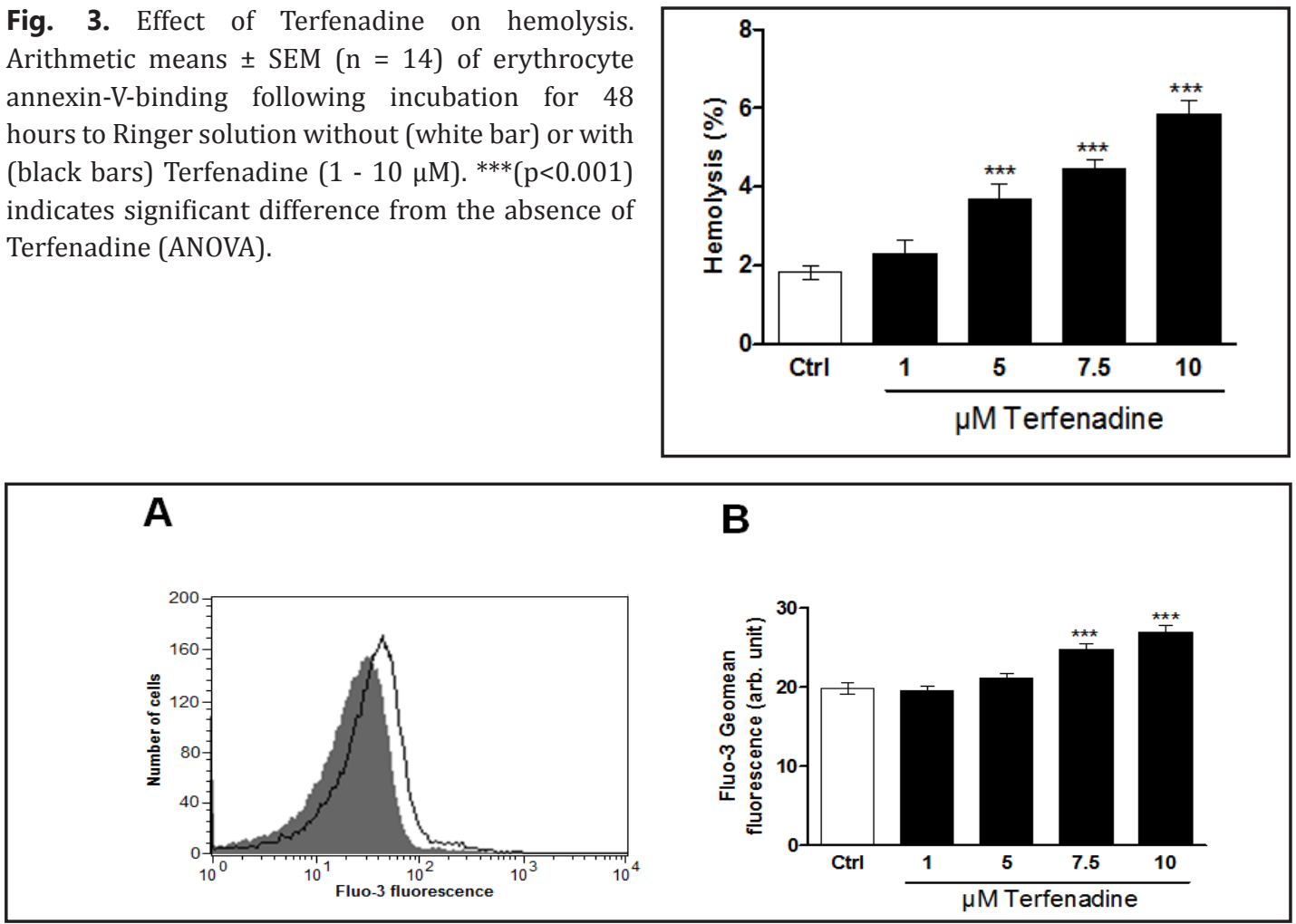

Fig. 4. Effect of Terfenadine on cytosolic $\mathrm{Ca}^{2+}$ activity. A. Original histogram of Fluo3-fluorescence in erythrocytes following exposure for 48 hours to Ringer solution without (grey area) and with (black line) presence of $10 \mu \mathrm{M}$ Terfenadine. B. Arithmetic means \pm SEM ( $n=14$ ) of erythrocyte annexin-V-binding following incubation for 48 hours to Ringer solution without (white bar) or with (black bars) Terfenadine $(1-10 \mu \mathrm{M}) .{ }^{* * *}(\mathrm{p}<0.001)$ indicates significant difference from the absence of Terfenadine (ANOVA).

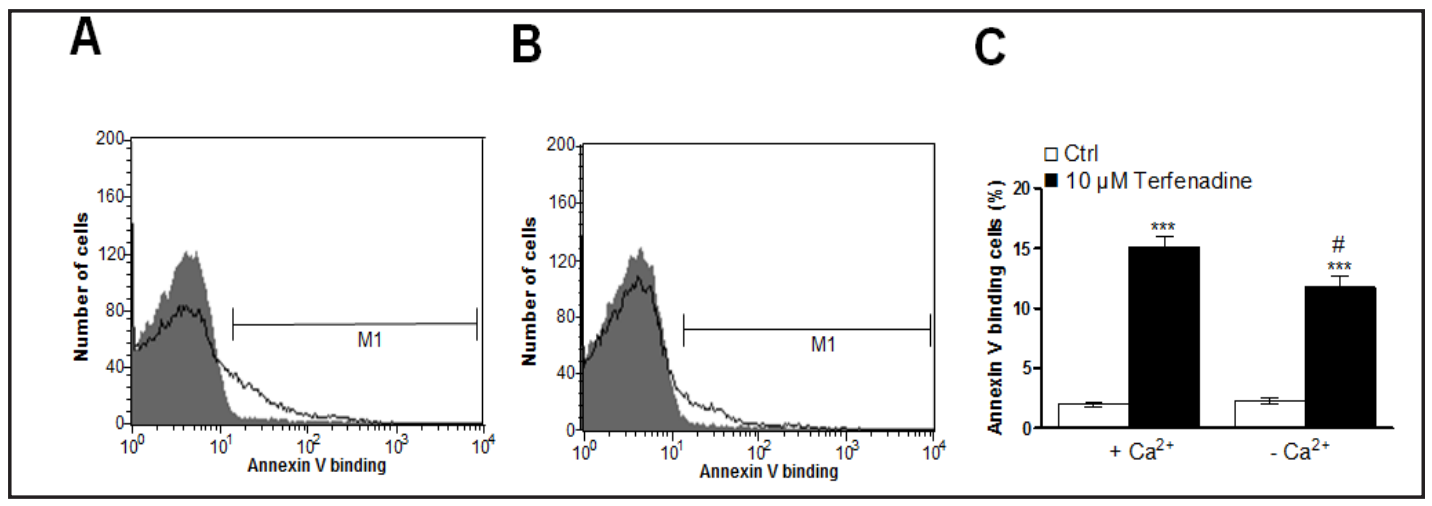

Fig. 5. $\mathrm{Ca}^{2+}$ sensitivity of Terfenadine -induced phosphatidylserine exposure. A,B. Original histograms of annexin-V-binding of erythrocytes following exposure for 48 hours to Ringer solution without (grey area) and with (black line) Terfenadine $(10 \mu \mathrm{M})$ in the presence (A) and absence (B) of extracellular $\mathrm{Ca}^{2+}$. C. Arithmetic means \pm SEM $(n=16)$ of annexin-V-binding of erythrocytes after a 48 hours treatment with Ringer solution without (white bars) or with (black bars) Terfenadine $(10 \mu \mathrm{M})$ in the presence (left bars, $\left.+\mathrm{Ca}^{2+}\right)$ and absence (right bars, $\left.-\mathrm{Ca}^{2+}\right)$ of $\mathrm{Ca}^{2+} . * * *(\mathrm{p}<0.001)$ indicates significant difference from the absence of Terfenadine, $\#(\mathrm{p}<0.05)$ indicates significant difference from the presence of $\mathrm{Ca}^{2+}$ (ANOVA).

extracellular $\mathrm{Ca}^{2+}$, Terfenadine significantly increased the percentage of annexin-V-binding erythrocytes. Thus, Terfenadine was effective in part, but not fully by stimulating entry of extracellular $\mathrm{Ca}^{2+}$. 


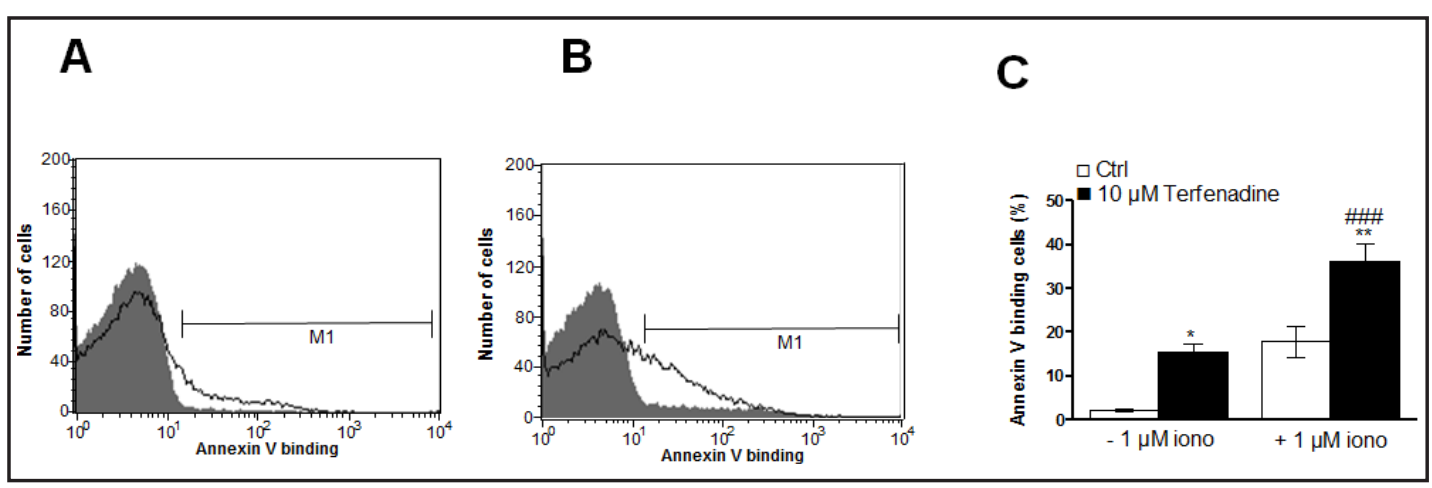

Fig. 6. Terfenadine-sensitivity of ionomycin-induced phosphatidylserine exposure. A,B. Original histograms of annexin-V-binding of erythrocytes without (grey area) and with (black line) a 48 hours Terfenadine (10 $\mu \mathrm{M}$ ) pretreatment and without (A) and with (B) a 15 min exposure to ionomycin $(1 \mu \mathrm{M})$. C. Arithmetic means \pm SEM ( $n=5)$ of annexin-V-binding of erythrocytes without (left bars, $-1 \mu \mathrm{M}$ iono) and with (right bars, + $1 \mu \mathrm{M}$ iono) a 15 min exposure to ionomycin $(1 \mu \mathrm{M})$ without (white bars) and with (black bars) a 48 hours Terfenadine $(10 \mu \mathrm{M})$ pretreatment. ${ }^{*}(\mathrm{p}<0.05),{ }^{* *}(\mathrm{p}<0.01)$ indicates significant difference from the absence of Terfenadine, \#\#\#(p<0.001) indicates significant difference from the absence of ionomycin (ANOVA).

In order to test whether Terfenadine enhanced the $\mathrm{Ca}^{2+}$ sensitivity of cell membrane scrambling, erythrocytes were incubated for 48 hours in the absence or presence of 10 $\mu \mathrm{M}$ Terfenadine and subsequently loaded with $\mathrm{Ca}^{2+}$ by a 15 minute treatment with the $\mathrm{Ca}^{2+}$ ionophore ionomycin $(1 \mu \mathrm{M})$. As shown in Fig. 6 , the pretreatment with $10 \mu \mathrm{M}$ Terfenadine significantly increased the percentage of annexin-V-binding erythrocytes and significantly augmented the stimulating effect of ionomycin on the percentage of annexin-V-binding erythrocytes. Thus, Terfenadine sensitized the erythrocytes for the scrambling effect of $\mathrm{Ca}^{2+}$ entry.

In order to test, whether Terfenadine induces oxidative stress, the abundance of reactive oxygen species (ROS) was quantified utilizing $2^{\prime}, 7^{\prime}$-dichlorodihydrofluorescein (DCF) diacetate. As a result, the DCF fluorescence was similar following a 48 hours incubation in Ringer with $10 \mu \mathrm{M}$ Terfenadine $(22.2 \pm 4.2$ a.u., $\mathrm{n}=10)$ and without Terfenadine $(24.7 \pm 3.2$ a.u., $\mathrm{n}=10$ ). Thus, Terfenadine did not appreciably induce oxidative stress.

In order to quantify ceramide abundance at the erythrocyte surface specific antibodies were used. As a result, the ceramide abundance was similar following a 48 hours incubation in Ringer with $10 \mu \mathrm{M}$ Terfenadine ( $9.9 \pm 0.3$ a.u., $\mathrm{n}=5)$ and in the absence of Terfenadine (11.3 \pm 0.4 a.u., $\mathrm{n}=5)$. Thus, Terfenadine did not appreciably induce ceramide abundance.

\section{Discussion}

The present observations uncover a novel effect of Terfenadine, i.e. the stimulation of erythrocyte cell membrane scrambling with phosphatidylserine translocation to the erythrocyte surface. The concentrations required for this effect are in the range of the concentrations required to trigger apoptosis of tumor cells [11]. Terfenadine may be particularly effective in clinical conditions with accelerated eryptosis, such as dehydration [27], hyperphosphatemia [28], chronic kidney disease (CKD) [29-32], hemolytic-uremic syndrome [33], diabetes [34], hepatic failure [35], malignancy [23], sepsis [36], sicklecell disease [23], beta-thalassemia [23], Hb-C and G6PD-deficiency [23], as well as Wilsons disease [37]. Moreover, Terfenadine may augment the eryptotic effect of other xenobiotics $[23,38-66]$ possibly leading to serious drug-drug interactions $[67,68]$.

The effect of Terfenadine on cell membrane scrambling was paralleled by an increase of cytosolic $\mathrm{Ca}^{2+}$ concentration $\left(\left[\mathrm{Ca}^{2+}\right]_{\mathrm{i}}\right)$ and blunted by removal of $\mathrm{Ca}^{2+}$ from extracellular space, indicating that entry of extracellular $\mathrm{Ca}^{2+}$ contributed to the stimulating effect of Terfenadine 


\section{Cellular Physiology Cell Physiol Biochem 2016;38:1425-1434

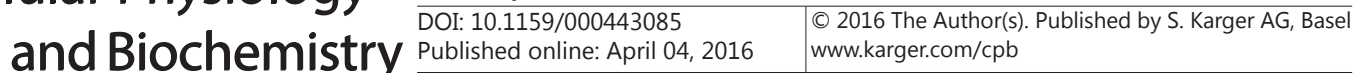 \\ Signoretto et al.: Terfenadine-Induced Eryptosis}

on phosphatidylserine translocation. Terfenadine did not appreciably influence the average forward scatter even though an increase of $\left[\mathrm{Ca}^{2+}\right]_{i}$ were expected to trigger activation of $\mathrm{Ca}^{2+}$ sensitive $\mathrm{K}^{+}$channels, $\mathrm{K}^{+}$exit, cell membrane hyperpolarization, $\mathrm{Cl}^{-}$exit and thus cellular loss of $\mathrm{KCl}$ with water [22]. Thus, some other effect of Terfenadine apparently prevented the decrease of cell volume despite increase of $\left[\mathrm{Ca}^{2+}\right]_{i}$.

Moreover, Terfenadine triggered cell membrane scrambling even in the absence of extracellular $\mathrm{Ca}^{2+}$, indicating that Terfenadine triggered cell membrane scrambling in part by mechanisms other than $\mathrm{Ca}^{2+}$ entry. Terfenadine further augmented the cell membrane scrambling triggered by ionomycin, $\mathrm{a} \mathrm{Ca}^{2+}$ ionophore flooding the cell with $\mathrm{Ca}^{2+}$. Thus, Terfenadine sensitizes apparently the cell membrane scrambling to the stimulating effects of $\mathrm{Ca}^{2+}$. Additional mechanisms able to trigger eryptosis include oxidative stress and ceramide [23]. However, Terfenadine triggered cell membrane scrambling without enhancing the abundance of reactive oxygen species or ceramide. Thus, the additional mechanism(s) involved in the stimulation of erythrocyte cell membrane scrambling remained elusive.

Besides inducing cell membrane scrambling, Terfenadine triggers hemolysis. Hemolysis leads to release of hemoglobin, which passes the renal glomerular filter, precipitates in the acidic lumen of renal tubules, occludes nephrons and thus may lead to renal failure [69]. As a matter of fact eryptosis is intended to precede hemolysis and thus to prevent the release of hemoglobin [23]. Eryptosis further counteracts development of parasitemia in malaria, as infected erythrocytes enter eryptosis and are thus cleared from circulating blood [23].

If the loss of erythrocytes due to stimulation of eryptosis and subsequent clearance of phosphatidylserine exposing erythrocytes from circulating blood outcasts the formation of new erythrocytes by erythropoiesis, anemia develops [23]. Phosphatidylserine exposing erythrocytes further adhere to the vascular wall [70], stimulate blood clotting and thus foster thrombosis [71-73]. Stimulation of eryptosis may thus impair microcirculation [24, 71, 74-77].

In conclusion, Terfenadine triggers cell membrane scrambling with phosphatidylserine translocation to the erythrocyte surface, an effect in part due to $\mathrm{Ca}^{2+}$ entry.

\section{Acknowledgements}

The authors acknowledge the meticulous preparation of the manuscript by Tanja Loch. The study was supported by the Deutsche Forschungsgemeinschaft and the Open Access Publishing Fund of Tuebingen University.

\section{Disclosure Statement}

The authors of this manuscript state that they have no conflicts of interest to declare.

\section{References}

1 Chen C: Some pharmacokinetic aspects of the lipophilic terfenadine and zwitterionic fexofenadine in humans. Drugs R D 2007;8:301-314.

2 Azevedo M: Topical levocabastine-a review of therapeutic efficacy compared with topical sodium cromoglycate and oral terfenadine on days with high pollen counts. Mediators Inflamm 1995;4:S21-25.

3 Zhang MQ, Timmerman H: Terfenadine: a mixture of equipotent antihistamine enantiomers without a clear 'isomeric ballast'. Pharm World Sci 1993;15:186-192.

4 Aaronson DW: Effects of terfenadine on psychomotor performance. An overview. Drug Saf 1993;8:321-329.

5 Jankowski R, Wagenmann M, Baroody FM, Naclerio R: Effect of terfenadine on nasal provocation. Int Arch Allergy Immunol 1993;101:311-317.

6 McTavish D, Goa KL, Ferrill M: Terfenadine. An updated review of its pharmacological properties and therapeutic efficacy. Drugs 1990;39:552-574.

7 Carter CA, Wojciechowski NJ, Hayes JM, Skoutakis VA, Rickman LA: Terfenadine, a nonsedating antihistamine. Drug Intell Clin Pharm 1985;19:812-817. 


\section{Cellular Physiology Cell Physiol Biochem 2016;38:1425-1434

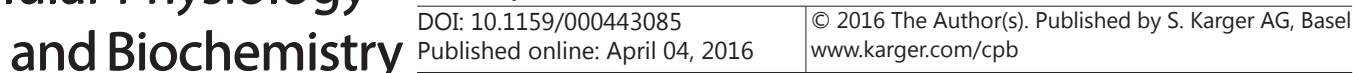 \\ Signoretto et al.: Terfenadine-Induced Eryptosis}

8 Sorkin EM, Heel RC: Terfenadine. A review of its pharmacodynamic properties and therapeutic efficacy. Drugs 1985;29:34-56.

9 Ciprandi G, Iudice A, Tosca MA, Ruffoni S, Buscaglia S, Canonica GW: Comparative effects of terfenadine and loratadine in the treatment of hay fever. J Investig Allergol Clin Immunol 1991;1:368-372.

10 Brooks CD, Karl KJ, Francom SF: Profile of ragweed hay fever symptom control with terfenadine started before or after symptoms are established. Clin Exp Allergy 1990;20:21-26.

11 Jangi SM, Ruiz-Larrea MB, Nicolau-Galmes F, Andollo N, Arroyo-Berdugo Y, Ortega-Martinez I, DiazPerez JL, Boyano MD: Terfenadine-induced apoptosis in human melanoma cells is mediated through $\mathrm{Ca} 2+$ homeostasis modulation and tyrosine kinase activity, independently of $\mathrm{H} 1$ histamine receptors. Carcinogenesis 2008;29:500-509.

12 Nicolau-Galmes F, Asumendi A, Alonso-Tejerina E, Perez-Yarza G, Jangi SM, Gardeazabal J, Arroyo-Berdugo Y, Careaga JM, Diaz-Ramon JL, Apraiz A, Boyano MD: Terfenadine induces apoptosis and autophagy in melanoma cells through ROS-dependent and -independent mechanisms. Apoptosis 2011;16:1253-1267.

13 Wang WT, Chen YH, Hsu JL, Leu WJ, Yu CC, Chan SH, Ho YF, Hsu LC, Guh JH: Terfenadine induces antiproliferative and apoptotic activities in human hormone-refractory prostate cancer through histamine receptor-independent Mcl-1 cleavage and Bak up-regulation. Naunyn Schmiedebergs Arch Pharmacol 2014;387:33-45.

14 Blaya B, Nicolau-Galmes F, Jangi SM, Ortega-Martinez I, Alonso-Tejerina E, Burgos-Bretones J, Perez-Yarza G, Asumendi A, Boyano MD: Histamine and histamine receptor antagonists in cancer biology. Inflamm Allergy Drug Targets 2010;9:146-157.

15 Chen C, Li G, Liao W, Wu J, Liu L, Ma D, Zhou J, Elbekai RH, Edin ML, Zeldin DC, Wang DW: Selective inhibitors of CYP2J2 related to terfenadine exhibit strong activity against human cancers in vitro and in vivo. J Pharmacol Exp Ther 2009;329:908-918.

16 Jangi SM, Diaz-Perez JL, Ochoa-Lizarralde B, Martin-Ruiz I, Asumendi A, Perez-Yarza G, Gardeazabal J, DiazRamon JL, Boyano MD: H1 histamine receptor antagonists induce genotoxic and caspase-2-dependent apoptosis in human melanoma cells. Carcinogenesis 2006;27:1787-1796.

17 Liu JD, Wang YJ, Chen CH, Yu CF, Chen LC, Lin JK, Liang YC, Lin SY, Ho YS: Molecular mechanisms of G0/G1 cell-cycle arrest and apoptosis induced by terfenadine in human cancer cells. Mol Carcinog 2003;37:39-50.

18 Wang YJ, Yu CF, Chen LC, Chen CH, Lin JK, Liang YC, Lin CH, Lin SY, Chen CF, Ho YS: Ketoconazole potentiates terfenadine-induced apoptosis in human Hep G2 cells through inhibition of cytochrome p450 3A4 activity. J Cell Biochem 2002;87:147-159.

19 Hadzijusufovic E, Peter B, Gleixner KV, Schuch K, Pickl WF, Thaiwong T, Yuzbasiyan-Gurkan V, Mirkina I, Willmann M, Valent P: H1-receptor antagonists terfenadine and loratadine inhibit spontaneous growth of neoplastic mast cells. Exp Hematol 2010;38:896-907.

20 Aichberger KJ, Mayerhofer M, Vales A, Krauth MT, Gleixner KV, Bilban M, Esterbauer H, Sonneck K, Florian S, Derdak S, Pickl WF, Agis H, Falus A, Sillaber C, Valent P: The CML-related oncoprotein BCR/ABL induces expression of histidine decarboxylase (HDC) and the synthesis of histamine in leukemic cells. Blood 2006;108:3538-3547.

21 Modlin IM, Lawton GP, Tang LH, Geibel J, Abraham R, Darr U: The mastomys gastric carcinoid: aspects of enterochromaffin-like cell function. Digestion 1994;55:S31-37.

22 Lang PA, Kaiser S, Myssina S, Wieder T, Lang F, Huber SM: Role of Ca2+-activated K+ channels in human erythrocyte apoptosis. Am J Physiol Cell Physiol 2003;285:C1553-C1560.

23 Lang E, Lang F: Mechanisms and pathophysiological significance of eryptosis, the suicidal erythrocyte death. Semin Cell Dev Biol 2015;39:35-42.

24 Abed M, Towhid ST, Mia S, Pakladok T, Alesutan I, Borst O, Gawaz M, Gulbins E, Lang F: Sphingomyelinaseinduced adhesion of eryptotic erythrocytes to endothelial cells. Am J Physiol Cell Physiol 2012;303:C991999.

25 Lau IP, Chen H, Wang J, Ong HC, Leung KC, Ho HP, Kong SK: In vitro effect of CTAB- and PEG-coated gold nanorods on the induction of eryptosis/erythroptosis in human erythrocytes. Nanotoxicology 2012;6:847856.

26 Maellaro E, Leoncini S, Moretti D, Del Bello B, Tanganelli I, De Felice C, Ciccoli L: Erythrocyte caspase-3 activation and oxidative imbalance in erythrocytes and in plasma of type 2 diabetic patients. Acta Diabetol 2013;50:489-495.

27 Abed M, Feger M, Alzoubi K, Pakladok T, Frauenfeld L, Geiger C, Towhid ST, Lang F: Sensitization of erythrocytes to suicidal erythrocyte death following water deprivation. Kidney Blood Press Res 2013;37:567-578. 


\section{Cellular Physiology Cell Physiol Biochem 2016;38:1425-1434 \begin{tabular}{ll|l} 
and Biochemistry & $\begin{array}{l}\text { DOI: 10.1159/000443085 } \\
\text { Published online: April 04, } 2016\end{array}$ & $\begin{array}{l}\text { C } 2016 \text { The Author(s). Published by S. Karger AG, Basel } \\
\text { www.karger.com/cpb }\end{array}$ \\
\hline
\end{tabular}

28 Voelkl J, Alzoubi K, Mamar AK, Ahmed MS, Abed M, Lang F: Stimulation of suicidal erythrocyte death by increased extracellular phosphate concentrations. Kidney Blood Press Res 2013;38:42-51.

29 Abed M, Artunc F, Alzoubi K, Honisch S, Baumann D, Foller M, Lang F: Suicidal erythrocyte death in endstage renal disease. J Mol Med (Berl) 2014;92:871-879.

30 Ahmed MS, Langer H, Abed M, Voelkl J, Lang F: The uremic toxin acrolein promotes suicidal erythrocyte death. Kidney Blood Press Res 2013;37:158-167.

31 Polak-Jonkisz D, Purzyc L: Ca(2+) influx versus efflux during eryptosis in uremic erythrocytes. Blood Purif 2012;34:209-210; author reply 210.

32 Calderon-Salinas JV, Munoz-Reyes EG, Guerrero-Romero JF, Rodriguez-Moran M, Bracho-Riquelme RL, Carrera-Gracia MA, Quintanar-Escorza MA: Eryptosis and oxidative damage in type 2 diabetic mellitus patients with chronic kidney disease. Mol Cell Biochem 2011;357:171-179.

33 Lang PA, Beringer O, Nicolay JP, Amon O, Kempe DS, Hermle T, Attanasio P, Akel A, Schafer R, Friedrich B, Risler T, Baur M, Olbricht CJ, Zimmerhackl LB, Zipfel PF, Wieder T, Lang F: Suicidal death of erythrocytes in recurrent hemolytic uremic syndrome. J Mol Med (Berl) 2006;84:378-388.

34 Nicolay JP, Schneider J, Niemoeller OM, Artunc F, Portero-Otin M, Haik G, Jr., Thornalley PJ, Schleicher E, Wieder T, Lang F: Stimulation of suicidal erythrocyte death by methylglyoxal. Cell Physiol Biochem 2006;18:223-232.

35 Lang E, Gatidis S, Freise NF, Bock H, Kubitz R, Lauermann C, Orth HM, Klindt C, Schuier M, Keitel V, Reich M, Liu G, Schmidt S, Xu HC, Qadri SM, Herebian D, Pandyra AA, Mayatepek E, Gulbins E, Lang F, Haussinger D, Lang KS, Foller M, Lang PA: Conjugated bilirubin triggers anemia by inducing erythrocyte death. Hepatology 2015;61:275-284.

36 Kempe DS, Akel A, Lang PA, Hermle T, Biswas R, Muresanu J, Friedrich B, Dreischer P, Wolz C, Schumacher U, Peschel A, Gotz F, Doring G, Wieder T, Gulbins E, Lang F: Suicidal erythrocyte death in sepsis. J Mol Med (Berl) 2007;85:273-281.

37 Lang PA, Schenck M, Nicolay JP, Becker JU, Kempe DS, Lupescu A, Koka S, Eisele K, Klarl BA, Rubben H, Schmid KW, Mann K, Hildenbrand S, Hefter H, Huber SM, Wieder T, Erhardt A, Haussinger D, Gulbins E, Lang F: Liver cell death and anemia in Wilson disease involve acid sphingomyelinase and ceramide. Nat Med 2007;13:164-170.

38 Alzoubi K, Calabròa S, Bissinger R, Abed M, Faggio C, Lang F: Stimulation of Suicidal Erythrocyte Death by Artesunate. Cell Physiol Biochem 2014;34:2232-2244.

39 Alzoubi K, Egler J, Abed M, Lang F: Enhanced Eryptosis Following Auranofin Exposure. Cell Physiol Biochem 2015;37:1018-1028.

40 Arnold M, Bissinger R, Lang F: Mitoxantrone-induced suicidal erythrocyte death. Cell Physiol Biochem 2014;34:1756-1767.

41 Arnold M, Lang E, Modicano P, Bissinger R, Faggio C, Abed M, Lang F: Effect of nitazoxanide on erythrocytes. Basic Clin Pharmacol Toxicol 2014;114:421-426.

42 Bissinger R, Barking S, Alzoubi K, Liu G, Liu G, Lang F: Stimulation of Suicidal Erythrocyte Death by the Antimalarial Drug Mefloquine. Cell Physiol Biochem 2015;36:1395-1405.

43 Bissinger R, Bouguerra G, Stockinger K, Abbes S, Lang F: Triggering of Suicidal Erythrocyte Death by Topotecan. Cell Physiol Biochem 2015;37:1607-1618.

44 Bissinger R, Fischer S, Jilani K, Lang F: Stimulation of Erythrocyte Death by Phloretin. Cell Physiol Biochem 2014;34:2256-2265.

45 Jacobi J, Lang E, Bissinger R, Frauenfeld L, Modicano P, Faggio C, Abed M, Lang F: Stimulation of erythrocyte cell membrane scrambling by mitotane. Cell Physiol Biochem 2014;33:1516-1526.

46 Bouguerra G, Aljanadi O, Bissinger R, Abbes S, Lang F: Embelin-Induced Phosphatidylserine Translocation in the Erythrocyte Cell Membrane. Cell Physiol Biochem 2015;37:1629-1640.

47 Bouguerra G, Bissinger R, Abbes S, Lang F: Stimulation of Eryptosis by Narasin. Cell Physiol Biochem 2015;37:1807-1816.

48 Bouguerra G, Bissinger R, Abbes S, Lang F: Zopolrestat Induced Suicidal Death of Human Erythrocytes. Cell Physiol Biochem 2015;37:1537-1546.

49 Briglia M, Fazio A, Faggio C, Laufer S, Alzoubi K, Lang F: Triggering of Suicidal Erythrocyte Death by Ruxolitinib. Cell Physiol Biochem 2015;37:768-778.

50 Briglia M, Fazio A, Signoretto E, Faggio C, Lang F: Edelfosine Induced Suicidal Death of Human Erythrocytes. Cell Physiol Biochem 2015;37:2221-2230.

51 Calabro S, Alzoubi K, Faggio C, Laufer S, Lang F: Triggering of Suicidal Erythrocyte Death Following Boswellic Acid Exposure. Cell Physiol Biochem 2015;37:131-142. 


\section{Cellular Physiology Cell Physiol Biochem 2016;38:1425-1434

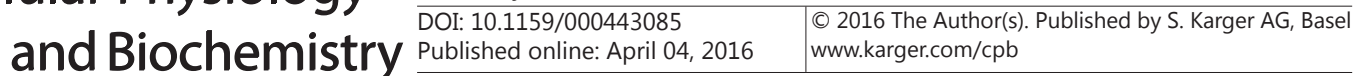 \\ Signoretto et al.: Terfenadine-Induced Eryptosis}

52 Egler J, Lang F: Licochalcone A Induced Suicidal Death of Human Erythrocytes. Cell Physiol Biochem 2015;37:2060-2070.

53 Faggio C, Alzoubi K, Calabro S, Lang F: Stimulation of suicidal erythrocyte death by PRIMA-1. Cell Physiol Biochem 2015;35:529-540.

54 Fazio A, Briglia M, Faggio C, Alzoubi K, Lang F: Stimulation of Suicidal Erythrocyte Death by Garcinol. Cell Physiol Biochem 2015;37:805-815.

55 Lang E, Jilani K, Bissinger R, Rexhepaj R, Zelenak C, Lupescu A, Lang F, Qadri SM: Vitamin D-Rich Diet in Mice Modulates Erythrocyte Survival. Kidney Blood Press Res 2015;40:403-412.

56 Lang E, Zelenak C, Eberhard M, Bissinger R, Rotte A, Ghashghaeinia M, Lupescu A, Lang F, Qadri SM: Impact of Cyclin-Dependent Kinase CDK4 Inhibition on Eryptosis. Cell Physiol Biochem 2015;37:1178-1186.

57 Lupescu A, Bissinger R, Goebel T, Salker MS, Alzoubi K, Liu G, Chirigiu L, Mack AF, Qadri SM, Lang F: Enhanced suicidal erythrocyte death contributing to anemia in the elderly. Cell Physiol Biochem 2015;36:773-783.

58 Lupescu A, Bissinger R, Herrmann T, Oswald G, Jilani K, Lang F: Induction of suicidal erythrocyte death by novobiocin. Cell Physiol Biochem 2014;33:670-680.

59 Malik A, Bissinger R, Calabro S, Faggio C, Jilani K, Lang F: Aristolochic Acid Induced Suicidal Erythrocyte Death. Kidney Blood Press Res 2014;39:408-419.

60 Officioso A, Alzoubi K, Manna C, Lang F: Clofazimine Induced Suicidal Death of Human Erythrocytes. Cell Physiol Biochem 2015;37:331-341.

61 Oswald G, Alzoubi K, Abed M, Lang F: Stimulation of suicidal erythrocyte death by ribavirin. Basic Clin Pharmacol Toxicol 2014;114:311-317.

62 Peter T, Bissinger R, Enkel S, Alzoubi K, Oswald G, Lang F: Programmed erythrocyte death following in vitro Treosulfan treatment. Cell Physiol Biochem 2015;35:1372-1380.

63 Stockinger K, Bissinger R, Bouguerra G, Abbes S, Lang F: Enhanced Eryptosis Following Exposure to Carnosic Acid. Cell Physiol Biochem 2015;37:1779-1791.

64 Tesoriere L, Attanzio A, Allegra M, Cilla A, Gentile C, Livrea MA: Oxysterol mixture in hypercholesterolemiarelevant proportion causes oxidative stress-dependent eryptosis. Cell Physiol Biochem 2014;34:10751089.

65 Waibel S, Bissinger R, Bouguerra G, Abbes S, Lang F: Saquinavir Induced Suicidal Death of Human Erythrocytes. Cell Physiol Biochem 2015;37:1973-1982.

66 Zierle J, Bissinger R, Egler J, Lang F: Lapatinib Induced Suicidal Death of Human Erythrocytes. Cell Physiol Biochem 2015;37:2275-2287.

67 Carlson AM, Morris LS: Coprescription of terfenadine and erythromycin or ketaconazole: an assessment of potential harm. J Am Pharm Assoc (Wash) 1996;NS36:263-269.

68 Thompson D, Oster G: Use of terfenadine and contraindicated drugs. JAMA 1996;275:1339-1341.

69 Harrison HE, Bunting H, Ordway NK, Albrink WS: The Pathogenesis of the Renal Injury Produced in the Dog by Hemoglobin or Methemoglobin. J Exp Med 1947;86:339-356.

70 Borst O, Abed M, Alesutan I, Towhid ST, Qadri SM, Foller M, Gawaz M, Lang F: Dynamic adhesion of eryptotic erythrocytes to endothelial cells via CXCL16/SR-PSOX. Am J Physiol Cell Physiol 2012;302:C644-C651.

71 Andrews DA, Low PS: Role of red blood cells in thrombosis. Curr Opin Hematol 1999;6:76-82.

72 Chung SM, Bae ON, Lim KM, Noh JY, Lee MY, Jung YS, Chung JH: Lysophosphatidic acid induces thrombogenic activity through phosphatidylserine exposure and procoagulant microvesicle generation in human erythrocytes. Arterioscler Thromb Vasc Biol 2007;27:414-421.

73 Zwaal RF, Comfurius P, Bevers EM: Surface exposure of phosphatidylserine in pathological cells. Cell Mol Life Sci 2005;62:971-988.

74 Closse C, Dachary-Prigent J, Boisseau MR: Phosphatidylserine-related adhesion of human erythrocytes to vascular endothelium. Br J Haematol 1999;107:300-302.

75 Gallagher PG, Chang SH, Rettig MP, Neely JE, Hillery CA, Smith BD, Low PS: Altered erythrocyte endothelial adherence and membrane phospholipid asymmetry in hereditary hydrocytosis. Blood 2003;101:46254627.

76 Pandolfi A, Di Pietro N, Sirolli V, Giardinelli A, Di Silvestre S, Amoroso L, Di Tomo P, Capani F, Consoli A, Bonomini M: Mechanisms of uremic erythrocyte-induced adhesion of human monocytes to cultured endothelial cells. J Cell Physiol 2007;213:699-709.

77 Wood BL, Gibson DF, Tait JF: Increased erythrocyte phosphatidylserine exposure in sickle cell disease: flow-cytometric measurement and clinical associations. Blood 1996;88:1873-1880. 